\title{
Material damping ratio from free-vibration method
}

\author{
KATARZYNA GABRYŚ, EMIL SOBÓL, WOJCIECH SAS, ALOJZY SZYMAŃSKI \\ Faculty of Civil and Environmental Engineering, Warsaw University of Life Sciences - SGGW, Poland
}

\begin{abstract}
Material damping ratio from free-vibration method. One important aspect of soil dynamics is attenuation or energy loses. This inherent dynamic property is essential in the analysis of soil behavior subjected to a dynamic load. Energy absorption in soils leads to the definition of an equivalent viscous damping ratio $(D)$. In resonant column testing there are commonly two different approaches in measuring material damping: during a steady-state vibration (SSV), when the specimen is vibrated at its first mode; and during free-vibration decay (FVD). The study reports results associated with the small to medium strain range material damping from FVD method, i.e. there is a cut off the constant vibration of the specimen at resonance and the specimen is allowed to free-vibration mode while the decay strain amplitude during free-vibration is calculated. The experiments were conducted on cohesive soils ( $\mathrm{sasiCl}, \mathrm{Cl}, \mathrm{clSa}$ ) from various test sites located in Warsaw, Poland. All the specimens were subjected to torsional mode of vibration at their first natural frequency, at different mean effective stress. The authors paid particular attention to the number of successive cycles after the free-vibration of the material is initiated. They examined various propositions from the literature and compare the received damping values using different number of cycles of vibration. The results showed that the most stable values of material damping ratio can be obtained by selecting each time a line of best fit on the authors' choice of number of free-vibration cycles. However, the number of these cycles should not exceed 10 .
\end{abstract}

Key words: damping testing, cohesive soils, laboratory tests, resonant column apparatus

\section{INTRODUCTION}

All real structures dissipate energy when they vibrate. The energy dissipated is often very small, so that an undamped analysis is sometimes realistic. However, when the damping is significant, its effect must be included in the analysis (Beards 1996).

Damping is utilized to characterize the ability of structures or subsoil to dissipate energy during dynamic response. It is usually difficult to model damping exactly, due to the fact that damping does not relate to an unique physical process, but to a number of possible processes. Damping values depend on several factors, among these are, e.g. vibration amplitude, material, structural configurations, fundamental periods of vibration, mode shape, etc. (Bachmann et al. 1995). In practice, several types of damping can be distinguished, i.e. hysteretic damping; viscous damping (velocity proportional damping); damping caused by wave scattering (scattering attenuation); radiation damping; numerical damping; damping as alternative (Yoshida 2015).

The paper focuses on the velocity proportional damping (the viscous damping), which is caused when the material with viscosity vibrates. Viscous damping 
is a common form of damping which is found in many engineering systems. The viscous damping force is proportional to the first power of the velocity across the damper, and it always opposes the motion, so that the damping force is a linear continuous function of the velocity (Beards 1996).

In the case of soils, it is well known that soils dissipate energy when subjected to cyclic loading such as that generated by earthquakes. This aspect of soil behaviour is commonly characterized in terms of a material damping coefficient which, for harmonic loading, can be measured in laboratory. There are two common measurements' methods, i.e. free-vibration decay (FVD) tests and stead-state vibration (SSV) tests (Lin 1988). Both methods are described in ASTM specification (1992). Theoretically, both methods should give identical results, though in practice, they are usually close to each other. Stead-state (SSV) method is easier and quicker and it is generally always used, whereas free-vibration (FVD) method is applied for occasional spot-checking. The procedures for both techniques are independent of whether longitudinal or torsional motion is under consideration (ASTM 1992).

The main objective of this paper is to report on the results of an experimental study relative to material damping from FVD method. For this purpose, samples of various cohesive soils ( $\mathrm{sasiCl}$, $\mathrm{Cl}, \mathrm{clSa}$ ) from various test sites located in Warsaw (Poland) are examined in a resonant column apparatus (RCA) in torsional mode of vibration to determine their damping ratio, denoted by $D$, using the following approach: there is a cut off the constant vibration of the specimen at resonance and the specimen is allowed to free-vibration mode while the decay strain amplitude during free-vibration is calculated.

\section{DAMPING FROM FREE-VIBRATION DECAY METHOD}

One of the most known devices to measure material damping is the resonant column apparatus. In the resonant column test a cylindrical specimen is excited in torsional steady-state vibration at its resonant frequency (Sas et al. 2017). After steady-state motion is established, the excitation power is rapidly halted, and the specimen is allowed to vibrate freely. The resulting free vibrations may be measured using the accelerometer mounted on the resonant column drive plate, as illustrated in Figure 1.

Damping is determined by calculating a logarithmic decrement $(\delta)$ from the decay curve. The logarithmic decrement is defined as the natural logarithm of the ratio of amplitudes of vibration on successive cycles (Soból et al. 2015, Gabryś et al. 2017):

$\delta=\ln \left(x_{i} / x_{i+1}\right)$

where:

$x_{i}$ - peak displacement on the $i$-th cycle; $x_{i+1}$ - peak displacement on the next $(i+1)$ cycle.

In the most cases, the logarithmic decrement is sufficient to describe material damping. However, for some geotechnical engineering applications damping is often expressed and reported in other forms, which are derived from $\delta$. The most common form for this purpose 


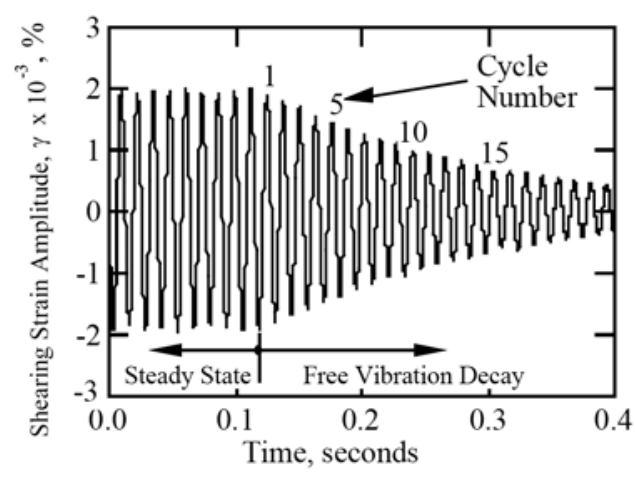

FIGURE 1. An example of free vibration decay curve (Stokoe et al. 1999)

is the damping ratio $(D)$ which represents the fraction of critical damping for a viscously damped, single-degree-of-freedom system. The damping ratio is calculated using the following formula:

$D=c / c_{c}$

where:

$c$ - viscous damping coefficient;

$c_{c}$ - critical damping coefficient.

Material damping ratio for a single-degree-of-freedom system can be estimated from the logarithmic decrement according to the equation (Lin 1988):

$D=\sqrt{\frac{\delta^{2}}{4 \pi^{2}-\delta^{2}}}$

Additionally, in ASTM specification (1992) two kinds of damping ratio from free vibration are distinguished, namely the rod damping ratio $\left(D_{L}\right)$ and the shear damping ratio $\left(D_{T}\right)$. Subscripts $L$ and $T$ are used to relate the damping ratios to the type of vibration applied in their determination. It should be remembered that damping ratio obtained from longitudinal vibration is not the same as this one from torsional vibration.

The logarithmic decrement during damping testing is determined by plotting the peak amplitude against the number of cycles (Fig. 2). In theory, this plot should be a straight line. The best fit slope of this line is equal to logarithmic decrement. The fit between 10 and 50 cycles is commonly used, according to RCA manual (GDS Resonant Column 2015). ASTM specification (1992) says that the number of free vibration cycles must be 10 or less. Bolton and Wilson (1990) have suggested to use the last five powered cycles, Stokoe et al. (1999) three successive cycles and Senetakis et al. (2015) two successive cycles when the FVD method is applied for damping derivation.
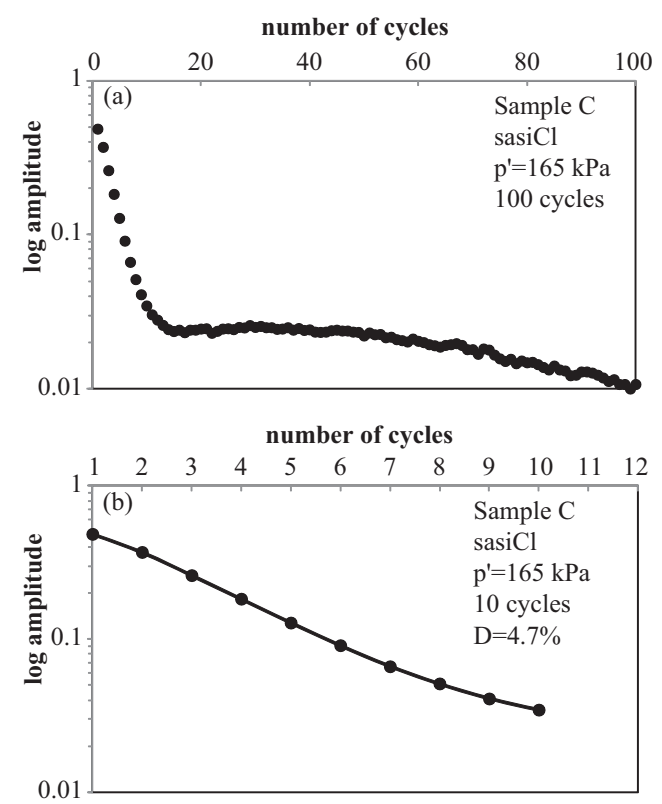

FIGURE 2. Log (peak amplitude) against number of cycles: $a$ - the total recorded data; $b-a$ line of best fit 
MATERIAL AND METHOD

\section{Testing material}

Six undisturbed soil samples (samples A, B, C, D, E, F - the table) from five different test sites located in Warsaw (Poland) were tested in this study. In accordance with Eurocode 7 (EN 1997), they represent the following soil types: clayey sand $(\mathrm{clSa})$, clay $(\mathrm{Cl})$ and sandy silty clay ( $\mathrm{sasiCl}$ ). Their grading curves are shown in Figure 3.

The first test site, from where samples A and D were collected, was located on one section of the expressway S2, between its two nodes: "Konotopa" and "Airport",

TABLE. Index properties and parameters of specimens tested

\begin{tabular}{|c|c|c|c|c|c|c|c|}
\hline Parameter & Unit & Sample A & Sample B & Sample C & Sample D & Sample E & Sample F \\
\hline $\begin{array}{c}\text { Soil type } \\
\text { after } \\
\text { PN-EN ISO }\end{array}$ & - & $\mathrm{clSa}$ & $\mathrm{Cl}$ & sasiCl & sasiCl & sasiCl & sasiCl \\
\hline$w$ & $\%$ & 14.43 & 26.04 & 13.58 & 17.41 & 10.78 & 11.76 \\
\hline$w_{P}$ & $\%$ & 12.72 & 33.11 & 12.82 & 14.70 & 13.68 & 12.46 \\
\hline$w_{L}$ & $\%$ & 31.50 & 70.95 & 27.82 & 35.55 & 21.50 & 28.80 \\
\hline$I_{P}$ & $\%$ & 18.78 & 37.84 & 15.00 & 20.85 & 7.82 & 16.34 \\
\hline$I_{L}$ & - & 0.091 & -0.187 & 0.050 & 0.130 & -0.370 & -0.043 \\
\hline$I_{C}$ & - & 0.909 & 1.187 & 0.950 & 0.870 & 1.370 & 1.043 \\
\hline$\rho$ & $\mathrm{kg} / \mathrm{m}^{3}$ & 2.12 & 1.94 & 2.19 & 2.10 & 2.26 & 2.12 \\
\hline
\end{tabular}

$w$ - the water content, $w_{P}$ - plastic limit, $w_{L}-$ liquid limit, $I_{P}$ - plasticity index, $I_{L}$ - liquidity index, $I_{C}$ - consistency index, $\rho$ - mass density.

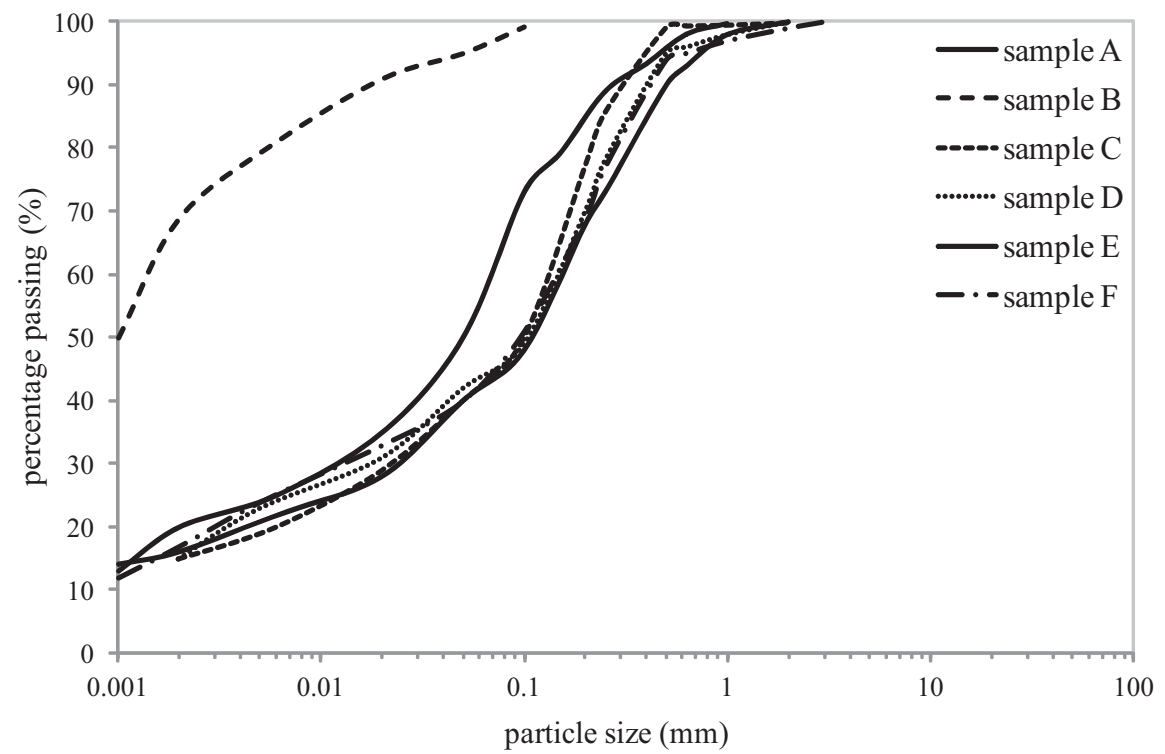

FIGURE 3. Grain size distribution of tested specimens 
in the area of the road embankment WD-18 (Soból et al. 2015, Sas et al. 2017). There, the complex of cohesive soils - from firm to very stiff clays with interbeds of sand was found. The second test site (sample B) was situated in Stegny, the southern district of Warsaw with a stratigraphy including the Quaternary deposits underlain by the overconsolidated Pliocene clays (Gabryś 2014). The third location (sample $\mathrm{C}$ ) is the region of Pełczyński street, in Bemowo, one of the western districts of Warsaw. Details of the geology of this test site can be found in Sas et al. (2017). Sample E was collected from the WULS-SGGW campus in Warsaw, at Jana Rodowicza "Anody" street (Gabryś et al. 2017) and sample $\mathrm{F}$ from the area of the new construction project "Fort Służew" located in the southern district of Warsaw, Ursynów. Due to the close localization of the two last test sites, their stratigraphy is very similar, consists of the Quaternary deposits including moraine clays and sandy clays.

The tested soil samples were extracted from different depths, from $2.0 \mathrm{~m}$ (sample A) up to approximately $10 \mathrm{~m}$ (sample B). They were in a stiff (ex. sample A) and very stiff (ex. sample B) consistency (PN-EN ISO 14688-1:2006/Ap2:2012). Sample B was a highly plastic soil, with a high plasticity index, sample E a slightly plastic, with the smallest plasticity index, whereas all the rest amediumplasticsoil(PN-B-02480:1986). Basic index properties of the specimens tested are shown in the table.

\section{Resonant column method}

In these research, the resonant column (RC) testing system was successfully employed, as a prime tool to investigate the viscous damping ratio of soil specimens in the shear strain range of $1.0^{-4}-1.0^{-2} \%$. The resonant column used is of Drnevich type and follows the fixed-free configuration. Details of the preparation of saturated samples and technical features of RC apparatus have been thoroughly described in Sas and Gabryś (2012), Gabryś et al. (2013) and Sas et al. (2015).

After performing the torsional resonance test, the resonant frequency of each specimen was determined and automatically updated into the damping test parameters. Subsequently, a sinusoidal wave was applied to the soil. The coils were switched off completely when a defined amount of time was finished (the default was mostly $2 \mathrm{~s}$, the exception is sample D). The drive system was left to vibrate free. Consequently, the resulting damping curve was measured. After the damping test was completed, every time the number of cycles for damping ratio calculations was adjusted. Therefore, the software produced a new value for logarithmic decrement, and next a new value for damping ratio. Moreover, in this study, only shear damping ratios were estimated.

Solid cylindrical specimens, with nominal diameter and height equal to 70 and $140 \mathrm{~mm}$, respectively, were subjected to various isotropic mean effective stress $\left(p^{\prime}\right)$. For sample A, $p$ ' amounted to 45, $90,135,180,225,270$ and $315 \mathrm{kPa}$, for sample B $p$ ' equalled $190 \mathrm{kPa}$, for sample $\mathrm{C} p$ ' equalled 55,110 and $165 \mathrm{kPa}$, for sample $\mathrm{D} p$ ' equalled $90 \mathrm{kPa}$, for sample $\mathrm{E} p$ ' equalled $75,150,225,300$ and $375 \mathrm{kPa}$ and for sample $\mathrm{F} p$ ' equalled 50, 100 and $200 \mathrm{kPa}$. Regarding the number 
of successive cycles after the free-vibration of the specimen was initiated, different approaches were implemented. In the case of samples A, B, C and D, the proposal implicated in RCA manual was examined, i.e. between 10 and 50 cycles. For sample E, the proposal presented in ASTM specification was studied, i.e. 10 or less cycles. For sample F, the standard approaches of two and three successive cycles were checked. Additionally, concerning sample $F$, the authors chose each time a specific number of free-vibration cycles, which allowed them to calculate a straight line of best fit. However, no more than 10 cycles have been used here.

The results from the experimental program are presented and discussed next.

\section{ANALYSIS OF THE TEST RESULTS}

A variation in the shear damping ratio $\left(D_{T}\right)$ with the shear strain $(\gamma)$ for various number of successive cycles in FVD method for samples A, B and C is given in Figure 4. Selected exemplary measurements obtained at different states of stress and application of a variable number of free vibration cycles, i.e. always 20 and additionally more (30, 40 and 50) or less (10) are presented here.

The test results clearly show that a smaller number of the cycles result in higher damping; the damping ratio reached a value close to $6 \%$ (sample B) and even to $10 \%$ (samples A and C). The smallest values of $D_{T}$, in the range of $1-2 \%$, were obtained for 50 cycles. Regardless of the soil type (clayey sand, clay or sandy silty clay) and the mean effective stress, similar results were achieved for 20 cycles; $D_{T}$ amounted to
2 and 4\%. In the case of samples $A$ and C, a two-fold increase in $D_{T}$ values was recorded using an ever smaller number of cycles; as for sample B nearly four-fold increase.

It can be further observed that dynamic shear damping increases with an increase in strain amplitude. It is certainly a non-linear increase, very pronounced for 10 cycles, although the authors did not succeed in choosing the best match for these data. Importantly, it can be seen that for cycles number more than 20, the changes in $D_{T}$ values with increase in strain amplitude are almost unnoticeable The maximum increase in $D_{T}$ with increasing $\gamma$ was registered for sample A and was around $8.7 \%$, then for sample C $7.6 \%$ and next for sample B 5.4\%. Similar observations can be drawn by analysing the results of sample D tests (Fig. 5).

The average value of $D_{T}$ was obtained from different oscillation times of the specimen $(2,4$ and $6 \mathrm{~s})$ at a given strain level. According to the literature (Soból et al. 2015), the damping ratio should increase curvilinear with the shear strain. Such a clear relationship can be noticed for $D_{T}$ calculated for 10 cycles. In addition, for 20 successive cycles, this trend can be still observed. However, the remaining data can be approximated with an almost horizontal straight line.

From Figures 4 and 5, it can be concluded that when the FVD method is used for damping derivation, the wave between the 20th and the 30th cycle is completely damped. The damping ratio will not show any dependencies except for a further decrease with the increase in cycles number included in the calculation, which results in its incorrect underestimation. 

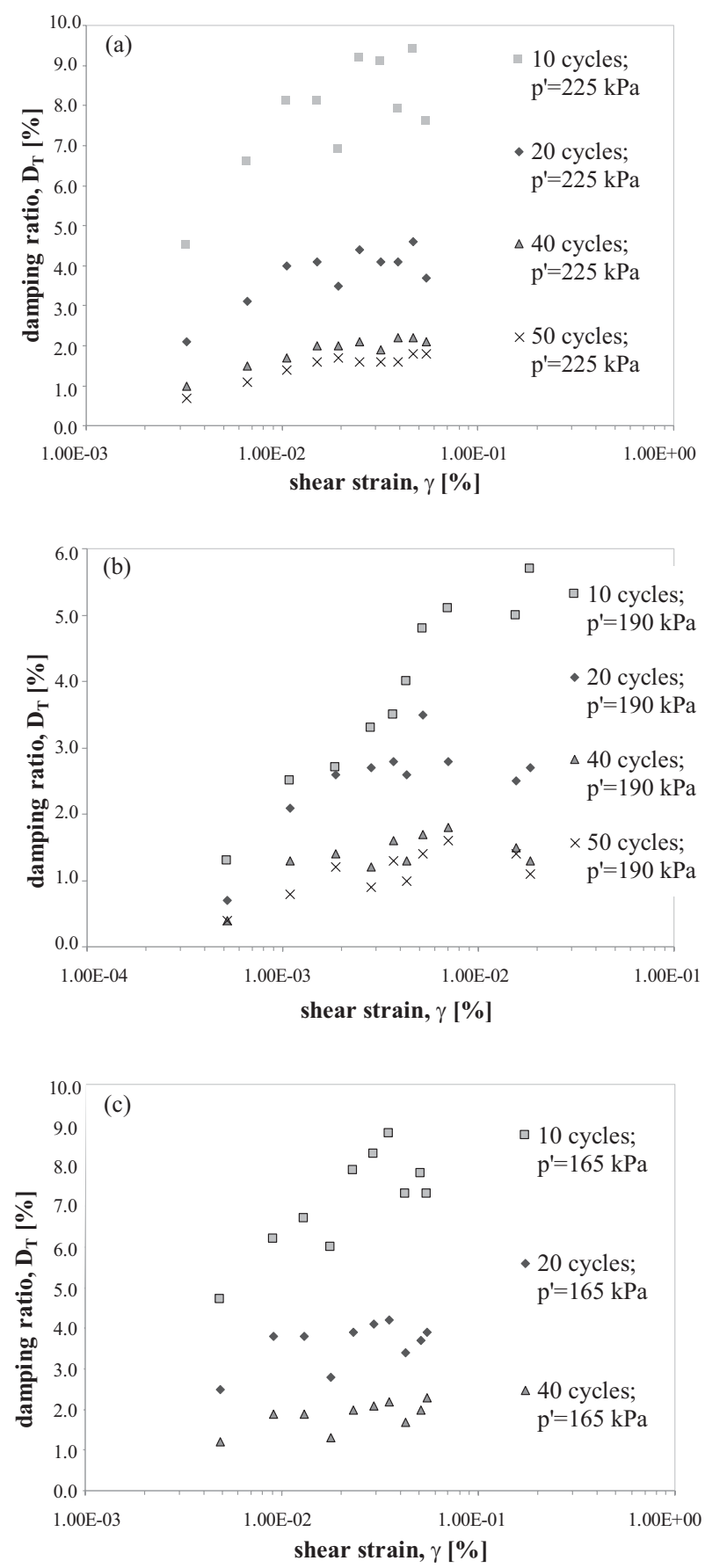

FIGURE 4. Shear damping ratio versus shear strain for (a) sample A; (b) sample B; (c) sample C 


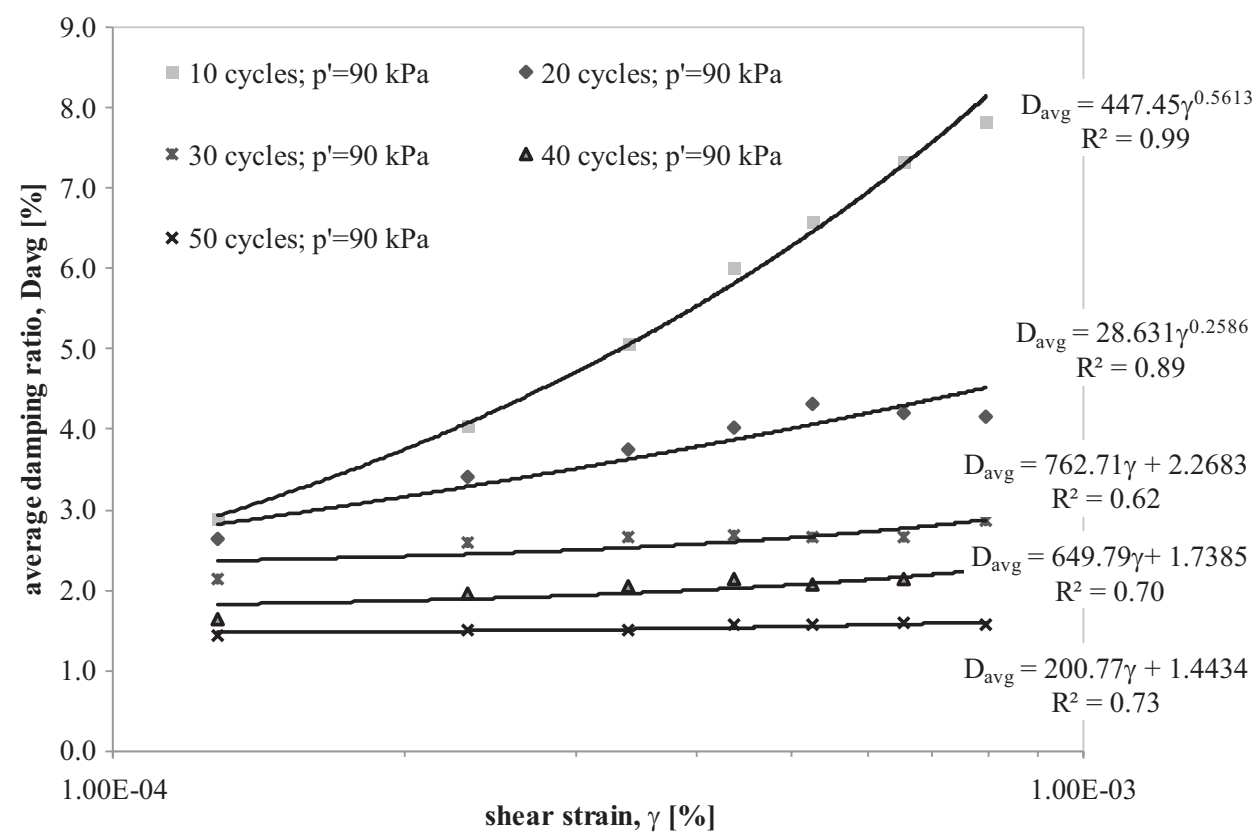

FIGURE 5. Average damping ratio versus shear strain for different cycles number - sample D

In the case of sample E, data of the last 10 (for shear strain less than $2 \cdot 10^{-3} \%$ ) and the last from 10 to 16 powered cycles (for shear strain more than $2 \cdot 10^{-3} \%$ ) as well as a succeeding decay of vibration, were recorded. The variation of the average damping ratio with strain for sample $\mathrm{E}$ is shown in Figure 6. It is an example of modified box-and-whisker plot, where the centre point means the mean value of $D_{T}$, the box itself was omitted, and only the whiskers left. The ends of the whiskers represent one standard deviation above and below $D_{\text {avg. }}$. Standard deviation (SDV) from the mean value of $D_{T}$ ranged of $0.04-0.36$ at average number of cycles up to 10 and decreased to $0.03-0.21$ at average number of cycles from 10 to 16. Comparing the average standard error of these two cases (Figs. $6 \mathrm{a}$ and $6 \mathrm{~b}$ ), the same value was obtained, at the level of 0.01 .
It should be noted that for the data points when the number of free-vibration cycles does not exceed 10, there is a very clear trend that $D_{\text {avg }}$ increases as $\gamma$ increases. A power-law best fitting curve was proposed here with a coefficient of determination $\left(R^{2}\right)$ of 0.96 (Fig. $6 a)$. For the data points when the number of free-vibration cycles was between 10 and 20, some monotonic trend could be also observed, but the mean values of $D_{T}$ were more scattered (Fig. 6b). Hence, it seems correct to state after ASTM specification (1992) that for calculations of material damping from FVD method, the number of free-vibration cycles must be 10 or less.

Next, on sample F, the authors examined the proposition of Senetakis et al. (2015) to implement two successive cycles (Figs. 7a, 8a, 9a), the suggestion of Stokoe et al. (1999) regarding three 

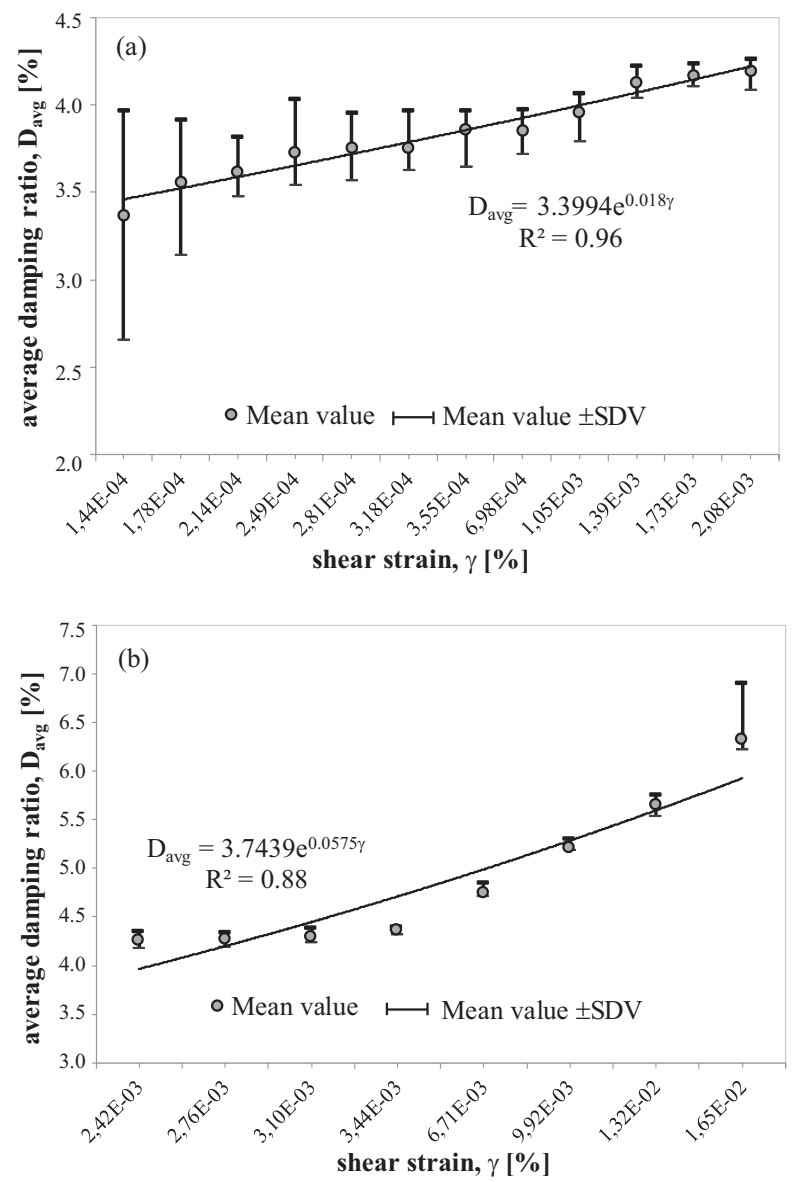

FIGURE 6. Illustration of the mean value \pm one standard deviation for damping ratio versus shear strain for sample E: a - average number of cycles - up to 10; b - average number of cycles - from 10 to 16

successive cycles (Figs. 7b, 8b, 9b) and, It was found that regardless of the for a comparison, their own selection of number of cycles used in the calculanumber of cycles, but up to 10, in order tion, the material damping from FVD to have a line of best fit based on this method showed a power-law dependchoice (Figs. 7c, 8c, 9c). In Figures 7, ence on the shear strain. The exception 8 and 9, typical dependences of the $D_{T}$ were the results for the effective stress values on $\gamma$ and $p$ ' can be observed. For equal to $200 \mathrm{kPa}$ (Fig. 9). This was probsample $\mathrm{F}$, for applied isotropic effective ably because of performing tests in the stresses from 50 to $200 \mathrm{kPa}, D_{\text {avg }}$ ranged, small-strain region, when the boundary in general, from 7.93 to $8.77 \%$ as $p^{\prime}$ of elastic-plastic deformations has not increased. While, along with the change been exceeded yet. Hence, the presented in $\gamma$ from $6.00 \cdot 10^{-4}$ to $5.81 \cdot 10^{-3} \%, D_{\text {avg }}$ results for $p^{\prime}=200 \mathrm{kPa}$ related more to the increased by an average of $2.13-0.44 \%$. small-strain material damping ratio $\left(D_{\min }\right)$. 

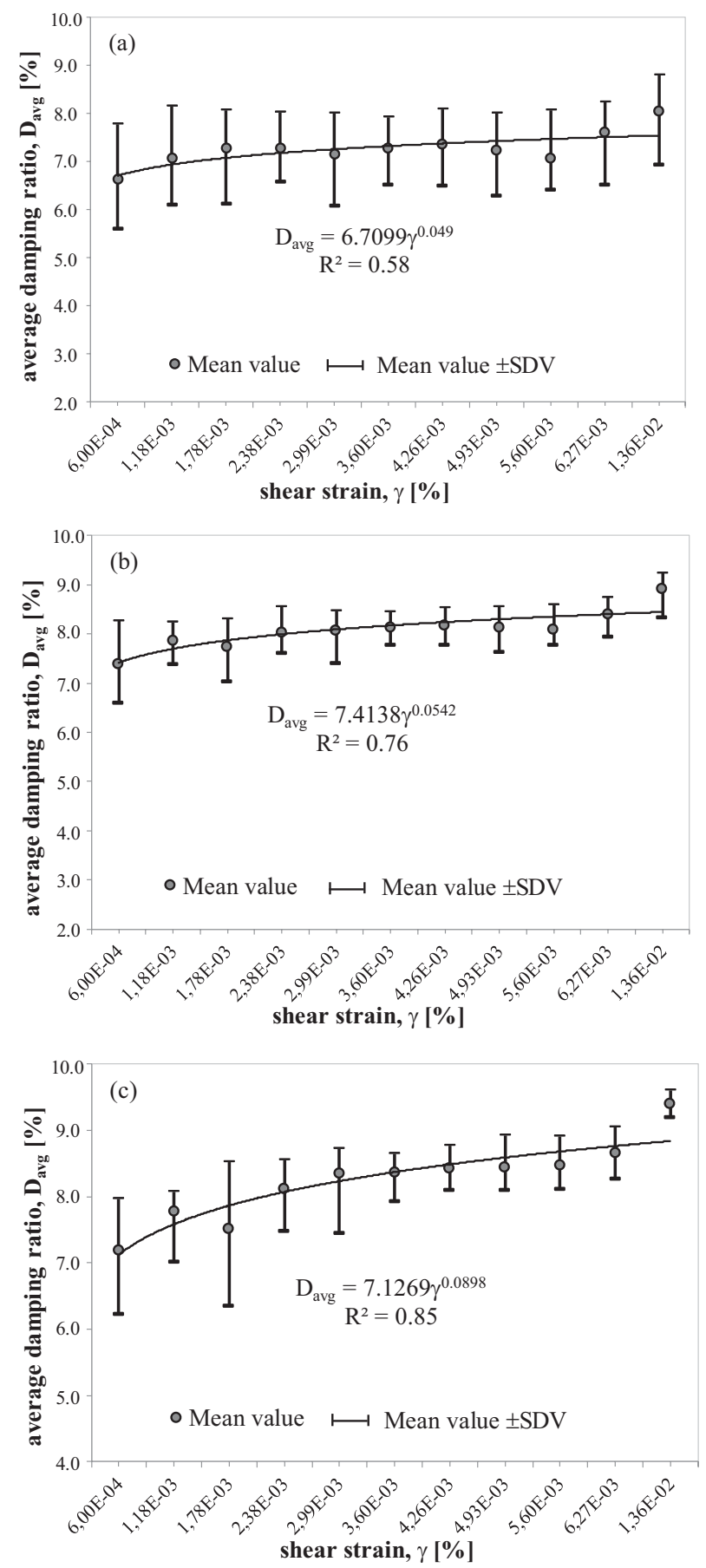

FIGURE 7. Illustration of the mean value \pm one standard deviation for damping ratio versus shear strain for sample $\mathrm{F}$ at $p^{\prime}=50 \mathrm{kPa}$ : a - number of cycles $-2 ; \mathrm{b}$ - number of cycles $-3 ; \mathrm{c}$ - average number of cycles - up to 10 

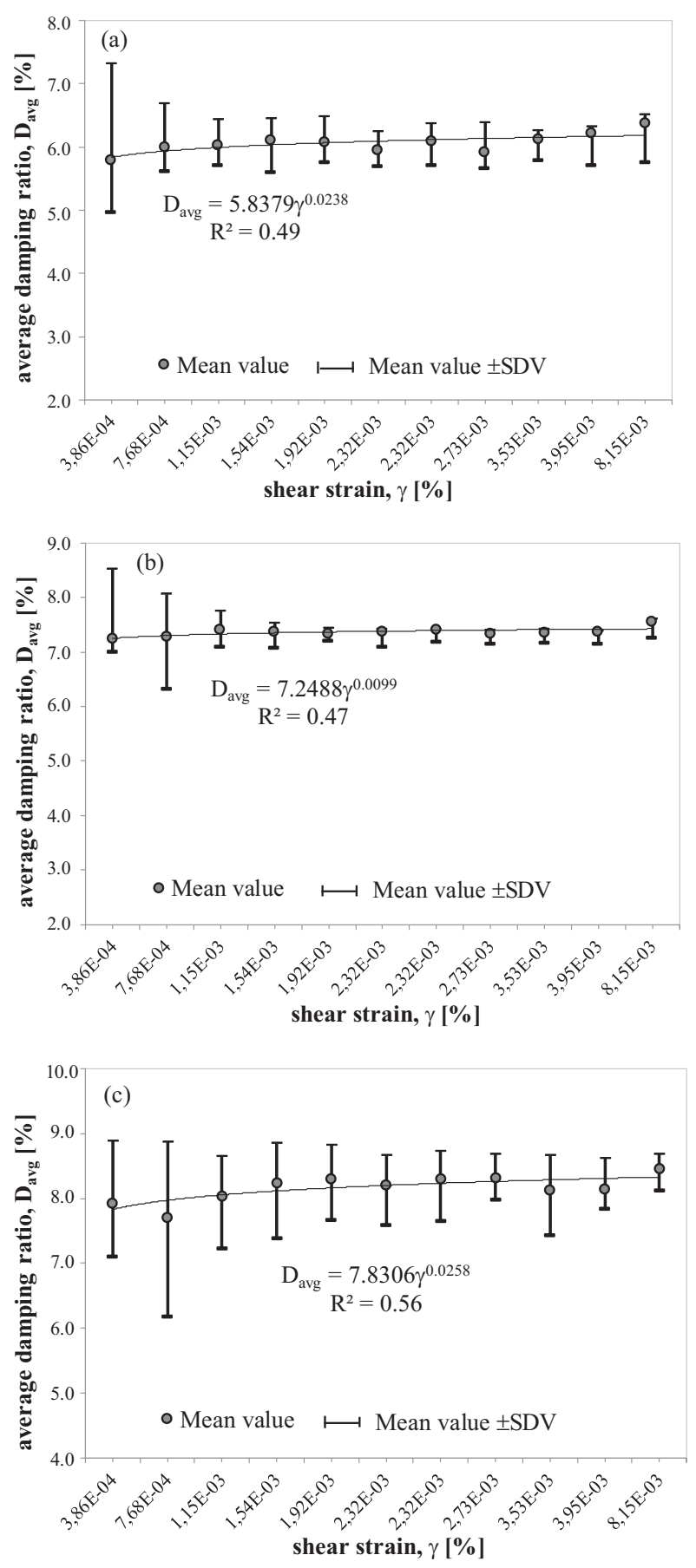

FIGURE 8. Illustration of the mean value \pm one standard deviation for damping ratio versus shear strain for sample $\mathrm{F}$ at $p^{\prime}=100 \mathrm{kPa}$ : a - number of cycles $-2 ; \mathrm{b}$ - number of cycles -3 ; c - average number of cycles - up to 10 

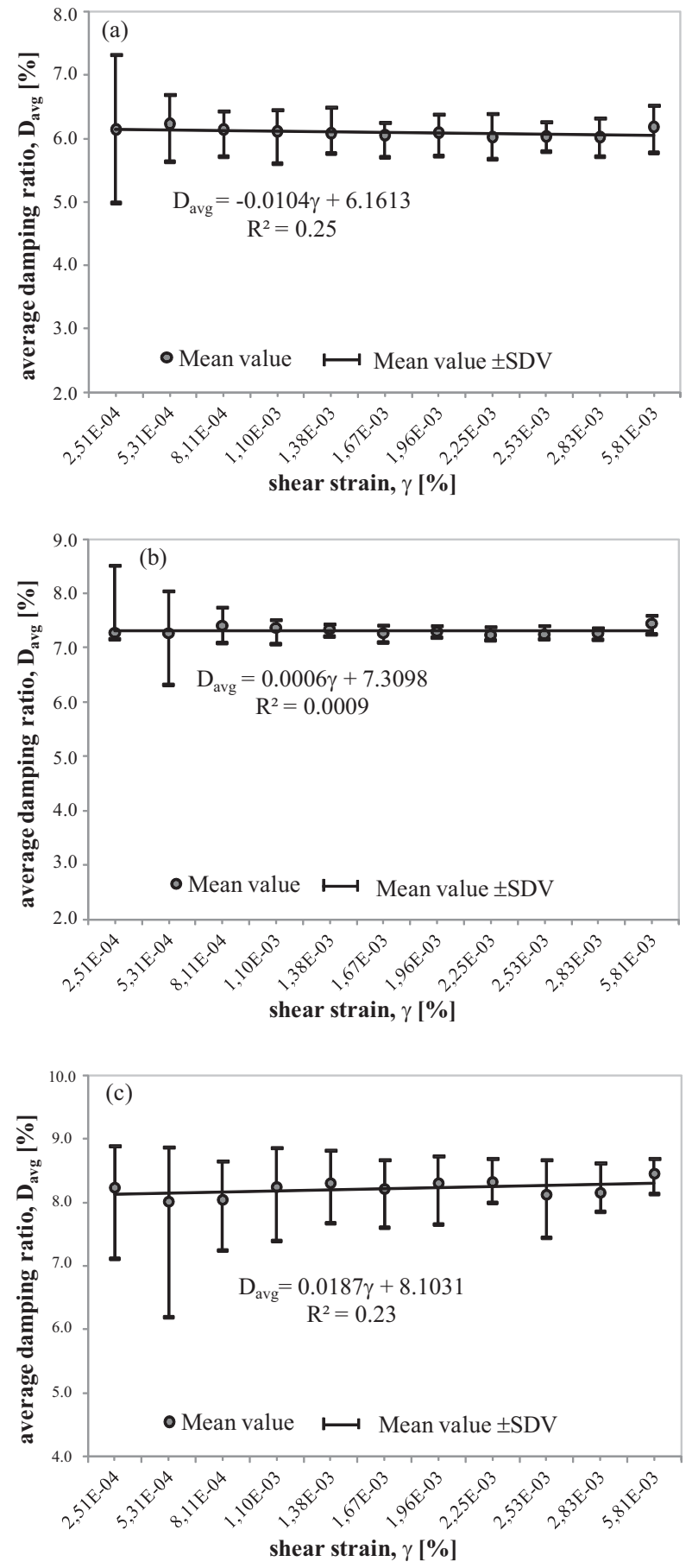

FIGURE 9. Illustration of the mean value \pm one standard deviation for damping ratio versus shear strain for sample $\mathrm{F}$ at $p^{\prime}=200 \mathrm{kPa}$ : a - number of cycles $-2 ; \mathrm{b}$ - number of cycles $-3 ; \mathrm{c}$ - average number of cycles - up to 10 
When analysing the data illustrated in Figures 7 and 8 , the coefficient of determination $\left(R^{2}\right)$ values for the power fitting presented in these figures increased together with the number of cycles. The best fit of the proposed model to the experimental data was obtained for the number of free vibration cycles up to $10, R^{2}=0.85$ (Fig. $7 \mathrm{c}$ ) and $R^{2}=0.56$ (Fig. 8c). However, the smallest value of the standard deviation from the mean value of average damping ratio as well as the average standard error were achieved when three successive cycles were implemented. It is worth noting that these values were only by hundredths smaller than in other cases of different cycles number.

\section{CONCLUSIONS}

The study reported experimental results derived from torsional resonant column tests on saturated cohesive soils collected from various test sites in Warsaw (Poland). Particular focus of this paper was put on material damping values from the free-vibration decay method. The authors implemented here various approaches in order to calculate average damping ratio $\left(D_{T}\right)$, differing from each other in the number of successive cycles after the free-vibration of the specimen was initiated.

It appeared that the number of free-vibration cycles should not exceed 10, as stated in the ASTM specification (1992). Additionally, the most stable values of material damping ratio can be obtained by selecting each time a line of best fit on the authors' choice of number of free-vibration cycles.
The principle of the correct average damping ratio calculation will be as follows. Every time, when a damping test is carried out and the logarithmic decrement of the decay curve is calculated, the decay must be checked carefully and it must be precisely determined how many cycles are needed for the whole decay.

\section{REFERENCES}

ASTM 1992: Standard test methods for modulus and damping of soils by the resonant column method: D4015-92. Annual book of ASTM standards. ASTM International, USA.

BACHMANN H., AMMANN W.J., DEISCHL F., EISENMANN J., FLOEGL I., HIRSCH G.H., KLEIN G.K., LANDE G.J., MAHRENHOLTZ O., NATKE H.G., NUSSBAUMER H., PRETLOVE A.J., RAINER J.H., SAEMANN E.U., STEINBEISSER L. 1995: Vibration Problems in Structures. Practical Guidelines. Birkhauser Verlag, Basel.

BEARDS C. 1996: Structural Vibration: Analysis and Damping. Elsevier. Linacre House, Jordan Hill, Oxford.

BOLTON M.D., WILSON J.M.R. 1990: Soil stiffness and damping. In: W.B. Kraetzing et al. (Eds.), Structural Dynamics. Balkema, Rotterdam: 209-216.

EN 1997. Eurocode 7. Geotechnical Design. General Rules.

GABRYŚ K. 2014: Charakterystyki odkształceniowe wybranych gruntów spoistych [Deformation characteristics of selected cohesive soils]. PhD dissertation, Warsaw University of Life Sciences - SGGW, Warsaw [typescript].

GABRYŚ K., SAS W., SZYMAŃSKI A. 2013: Kolumna rezonansowa jako urządzenie do badań dynamicznych gruntów spoistych [Resonant Column Apparatus as a device for dynamic testing of cohesive soils]. Prz. Nauk. Inż. Kszt. Środ. 22 (1): 3-13.

GABRYŚ K., SAS W., MARKOWSKA-LECH K., SOBÓL E., GŁUCHOWSKI A., BIENIAWSKI J. 2017: Laboratoryjne metody wyznaczania współczynnika thumienia drgań na przykładzie gruntu spoistego [Laboratory 
methods for determination of damping ratio on the example of cohesive soil]. Acta Sci. Pol. Architectura 16 (3): 13-24.

GDS Resonant Column 2015. The GDS Resonant Column System Handbook.

LIN M-L., NI S-H., WRIGHT S.G., STOKOE K.H. II 1988: Characterization of material damping in soil. In: Proceedings of Ninth World Conference on Earthquake Engineering, 02-09.08.1988, Tokyo-Kyoto, Japan. Vol. 3.

PN-B-02480:1986. Grunty budowlane. Określenia, symbole, podział i opis gruntów [Building soils. Terms, symbols, division and description of soils].

PN-EN ISO 14688-2:2006/Ap2:2012. Badania geotechniczne. Oznaczanie i klasyfikowanie gruntów. Część 2: Zasady klasyfikowania z nowym Załącznikiem krajowym NA [Geotechnical research. Determination and classification of soils. Part 2: Classification rules with the new National Annex NA].

SAS W., GABRYŚ K. 2012: Laboratory measurement of shear stiffness in resonant column apparatus. Acta Sci. Pol. Architectura 11 (4): 29-39.

SAS W., GABRYŚ K., SZYMAŃSKI A. 2015: Effect of time on dynamic shear modulus of selected cohesive soil of one section of Express Way No S2 in Warsaw. Acta Geoph. 63 (2): 398-413.

SAS W., GABRYŚ K., SZYMAŃSKI A. 2017: Experimental studies of dynamic properties of Quaternary clayey soils. Soil Dynam. Earthquake Eng. 95: 29-39.

SENETAKIS K., ANASTASIADIS A., PITILAKIS K. 2015: A comparison of material damping measurements in resonant column using the steady-state and free-vibration decay methods. Soil Dynam. Earthquake Eng. 74: $10-13$.

SOBÓL E., SAS W., SZYMAŃSKI A. 2015. Zastosowanie kolumny rezonansowej do określenia reakcji gruntów drobnoziarnistych obciążonych dynamicznie [The use of resonant column to determine the response of dynamically loaded fine grained soils]. Prz. Nauk. Inż. Kszt. Środ. 24 (2): 133-144.

STOKOE K.H. II., DARENDELI M.B., ANDRUS R.D., BROWN L.T. 1999: Dynamic soil properties: laboratory, field and correlation studies. In: Proceedings of Second Interna- tional Conference on Earthquake Geotechnical Engineering, 21-25.06.1999 Lisbon. Balkema, Rotterdam. Vol. 3: 811-845.

YOSHIDA N. 2015: Seismic Ground Response Analysis. Geotechnical, Geological and Earthquake Engineering 36. DOI 10.1007/978-94017-9460-2_2

Streszczenie: Materiałowy wspótczynnik tlumienia z krzywej gaśnięcia drgań swobodnych. Jednymi z ważnych aspektów dynamiki gruntów są thumienia lub straty energii. Te nieodłączne właściwości dynamiczne są bardzo istotne w analizie zachowania się gruntu poddanego obciążeniu dynamicznemu. Zjawisko pochłaniania energii $w$ gruncie prowadzi do określenia równoważnego współczynnika thumienia wiskotycznego. W badaniach w kolumnie rezonansowej mają zastosowanie dwa różne podejścia do pomiaru thumienia materiałowego: podczas drgań w stanie ustalonym (USD), gdy próbka drga w pierwszym trybie, i z krzywej gaśnięcia swobodnych drgań próbki (KGSD). Badania omówione w artykule przedstawiają wyniki thumienia materiałowego w zakresie małych i średnich odkształceń z metody KGSD, tzn. w momencie uzyskania drgań o stałej mocy ich wzbudzanie ustaje, a wythumiane przez próbkę wibracje są stopniowo zapisywane przez komputer. Badania przeprowadzono na gruntach spoistych (sasiCl, $\mathrm{Cl}, \mathrm{clSa}$ ) pochodzących z różnych poletek badawczych zlokalizowanych w Warszawie (Polska). Wszystkie próbki poddano drganiom skręcającym, przy ich pierwszej częstotliwości drgań własnych, przy różnych wartościach średniego naprężenia efektywnego. W opracowaniu zwrócono szczególną uwagę na liczbę kolejnych cykli po zainicjowaniu swobodnych drgań gruntu, przeanalizowano różne propozycje zawarte w literaturze i porównano otrzymane wartości współczynnika tłumienia obliczonego za pomocą różnej liczby cykli drgań. Na podstawie zaprezentowanych wyników stwierdzono, że najbardziej stabilne wartości współczynnika thumienia materiałowego można uzyskać, wybierając za każdym razem linię najlepszego dopasowania do zaproponowanej przez autorów liczby cykli swobodnych drgań. Liczba ta nie powinna jednak przekraczać 10 .

Stowa kluczowe: badanie tłumienia, grunty spoiste, badania laboratoryjne, kolumna rezonansowa 
MS received 23.02.2018

MS accepted 04.06.2018

Authors' address:

Katarzyna Gabryś, Emil Sobol, Wojciech Sas,

Alojzy Szymański

Wydział Budownictwa i Inżynierii Środowiska

Szkoła Główna Gospodarstwa Wiejskiego

w Warszawie

ul. Nowoursynowska 159, 02-776 Warszawa

Poland

e-mail: katarzyna_gabrys@sggw.pl

emil_sobol@sggw.pl

wojciech_sas@sggw.pl

alojzy_szymanski@sggw.pl 